\title{
PREVENSI DAN PROTEKSI KASUS BUNUH DIRI BERBASIS SEKOLAH
}

\author{
Lisya Chairani \\ kimi_bunda@yahoo.com \\ Psikolog
}

\begin{abstract}
This article discusses how suicide case can be prevented by the school based prevention and protection. Child has a special risk in suicide done by parent. Maybe the innoncent child will be brought together by parent for his/her suicide or the child will accept directly or nor the psychological impact of that case. Therefore, the suicide can be said as one the hardness to child, whether child as a victim, witness and or as the person who leaved by the parent with million questions in his/her mind. There are many factors cause one does the suicide. They are psychological, biological, and family environment. The prevention of suicide can be done by school based prevention and protection. This activity of course envoles the competence person in its area. The school has to foms the net working to be able to referl the student who has certain problem in order not to does suicide.
\end{abstract}

Kata Kunci: prilaku, bunuh diri, anak,orang tua

\section{PENDAHULUAN}

Bunuh diri menjadi berita yang selalu hangat dibicarakan, tidak hanya karena pelakunya tetapi juga karena korban dan modus operandinya. Belakangan ini kita dikejutkan dengan peristiwa ibu yang melakukan bunuh diri dan membawa serta anaknya, tidak hanya itu ada pula bapak yang juga 
membunuh diri bersama anaknya atau juga bunuh diri yang dilakukan oleh orang tua karena ketidak mampuan menahan beban tanggung jawab kehidupan. Bunuh diri dilakukan dengan berbagai modus, menegak obat anti nyamuk, meminum racun, menggantung diri hingga membakar diri.

Kasus-kasus yang menjadi perhatian publik terjadi di Kota Pekalongan, Jawa Tengah, yakni dua anak balita, Sabila Putri Khaera (3) dan Fadli Muhamad Nizan (4 bulan), ditemukan tewas di dalam bak kamar mandi, Sabtu malam pekan lalu. Sabila dan Fadli diduga dibenamkan oleh ibu kandung mereka, Ny YIY (25). Dalam keterangannya, Rabu kemarin, Ny YIY yang kondisinya masih labil mengatakan, selama empat tahun menikah dirinya tidak mendapat nafkah ekonomi yang layak. Sebelumnya, kasus serupa terjadi di Bekasi. Diduga stress Ny Is (35), 14 Maret lalu, membunuh kedua anaknya masing-masing Aldi Rasyid (4 bulan) dan Mutiara Yusuf (2 tahun) dengan cara dibenamkan di bak mandi.

Di Kota Malang, Jawa Timur, Ny JM bunuh diri dan sebelumnya membunuh keempat anak kandungnya sendiri. Meskipun keluarga membantah, tetapi polisi menyimpulkan pembunuhan massal ini terjadi karena beban hidup dan tekanan ekonomi yang menghimpit ${ }^{1}$. Penyebab semua peristiwa itu sebagaimana yang sering dilansir media massa adalah himpitan ekonomi dan masalah keluarga. Biasanya diagnosis akhir, pelaku dinyatakan mengalami gangguan mental tanpa ada lagi pemberitaan bagaimana cara memulihkan para pelaku terlebih lagi anak sebagai korban terlepas dari usaha bunuh diri berhasil atau tidak, anak memiliki resiko tersendiri atas peristiwa yang terjadi tersebut.

Anak yang tidak berdosa dan tidak pernah meminta untuk dilahirkan menjadi korban dari peristiwa bunuh diri. Pengaruhnya terhadap perkembangan anak, dapat bersifat langsung dan tidak langsung. Selama ini mungkin banyak orang mengira, masalah bunuh diri yang dilakukan oleh seseorang atau orang tua hanya berakhir saat jenazah dikuburkan. Namun tidak demikian adanya. Suatu proses panjang justru dibutuhkan untuk memulihkan keadaan bagi orang yang ditinggalkan.

Selama suatu peristiwa bunuh diri hanya dipandang sebagai sebuah tindakan yang dilakukan oleh seseorang dengan tujuan untuk mengakhiri hidupnya maka tidak banyak yang dapat kita lakukan. Tetapi tanpa kita sadari, peristiwa bunuh diri itu sendiri merupakan salah satu bentuk kekerasan kepada anak, apakah anak terlibat langsung sebagai korban, sebagai yang menyaksikan ataupun sebagai yang ditinggalkan dengan sejuta pertanyaan di benaknya.

Kita tidak peka memandang masalah ini sebagai salah satu masalah kesehatan mental anak, karena porsi dan prevalensinya yang tidak terdeteksi. Sebagaimana kebiasaan kita di negeri ini dalam mensikapi suatu masalah, menunggu suatu peritiwa besar terjadi baru dilakukan penanganan sehingga 
lupa bahwa melakukan deteksi lebih memudahkan untuk melakukan prevensi. Contoh sederhana adalah masalah keterbatasan pangan yang dialami oleh anak Indonesia. Ketika satu per satu anak-anak itu mati oleh keterbatasan pangan dan pelayanan kesehatan, kematian anak-anak itu tidak pernah dinyatakan sebagai "darurat". Baru sesudah dalam jumlah besar korban berjatuhan, lantas perhatian baru dicurahkan. Artinya, isu anak baru menjadi penting tatkala terjadi sorotan yang besar atas sejumlah nyawa yang melayang. Sifatnya sangat momental dan aksidental. Hal ini berdampak pada pola penyelesaiannya. Yang sifatnya selalu kuratif, emergensi, jangka pendek. In casu dan bukan sanate in radix. Yang sifatnya preventif, strategis, jangka panjang. Oleh karena itu, korban anak akan senantiasa berjatuhan. (YPHA, 2008)

Sudah saatnya kita peduli terhadap perkembangan anak sebagai asset bangsa penerus masa depan. Kesadaran tersebut harus dimulai dari keluarga sebagai lingkungan terkecil. Jika kita tidak ingin sumber daya manusia kita menjadi hilang untuk beberapa dekade dan membuat Negara ini tertinggal dari Negara-negara lainnya. Seterusnya kepedulian dapat dilanjutkan di tingkat sekolah. Tulisan ini akan membahas bagaimana sekolah dapat melakukan proteksi dan prevensi dan terhadap kasus-kasus bunuh diri.

\section{PEMBAHASAN}

\section{Memahami Bunuh Diri}

Pada umumnya peristiwa bunuh diri biasanya didahului oleh depresi yang melanda pelakunya. Depresi yang didahului oleh frustasi, yakni situasi di mana seseorang tidak mampu mencapai tujuan yang diinginkannya. Sedangkan frustasi didahului oleh stress, yakni respon individu terhadap keadaan yang mengancam dan mengganggu kemampuan seseorang untuk menghadapinya.

Suatu teori tentang bunuh diri yang didasari oleh penelitian dalam psikologi sosial dan kepribadian menyatakan bahwa beberapa tindakan bunuh diri dilakukan karena keinginan kuat untuk lari dari kesadaran yang menyakitkan atas kegagalan, dan kurang keberhasilan yang diatribusikan orang yang bersangkutan pada dirinya ${ }^{2}$. (Baumeister, dalam Davison, Neale \& Kring, 2006). Kesadaran ini diasumsikan menimbulkan penderitaan emosional yang berat, mungkin depresi. Ekspektansi tinggi yang tidak realistis sehingga kemungkinan gagal memenuhi ekspektansi tersebut memegang peranan penting dalam keputusan membunuh diri.

Shneidman 3 (dalam Davison, Neale \& Kring, 2006) menguraikan sepuluh hal umum tentang bunuh diri: (1) sasaran bunuh diri umumnya adalah untuk mencapai solusi, (2) tujuan bunuh diri umumnya adalah penghilangan kesadaran, (3) stimulus bunuh diri umumnya rasa sakit psikologis yang tidak bisa ditoleransi, (4) stressor dalam tindakan bunuh diri umumnya adalah kebutuhan psikologis yang tidak terpenuhi, (5) emosi yang umum dialami 
dalam bunuh diri adalah keputusasaan dan ketidakberdayaan,(6) kondisi kognitif yang umum dalam bunuh diri adalah ambivalensi, (7) kondisi perceptual yang umum dalam bunuh diri adalah bunuh diri merupakan keadaan terdesak, (8) tindakan yang umum dalam bunuh diri adalah aggression, (9) tindakan interpersonal yang umum dalam bunuh diri adalah pengungkapan niat, (10) konsistensi yang umum dalam bunuh diri adalah dengan pola coping sepanjang hidup.

Emil Durkheim (dalam Davison, Neale \& Kring, 2006) membedakan tiga jebih bunuh diri yaitu : bunuh diri egoistik dilakukan oleh orang yang memiliki sedikit keterikatan dengan keluarga masyarakat, atau komunitas. Orang-orang ini merasa terasingkan dari orang lain, tidak memiliki dukungan social yang penting agar mereka dapat tetap berfungsi secara adaptif sebagai makhluk social. ${ }^{4}$

Bunuh diri altruistic dianggap sebagai respon terhadap berbagai tuntutan social dan sebagai bentuk keterikatan dan pengorbanan seseorang pada suatu komunitas. Bunuh diri anomic dapat dipicu oleh perubahan mendadak dalam hubungan dengan masyarakat. Anomic adalah suatu situasi dimana seseorang meyakini cara hidup yang normal tidak mungkin lagi dilakukan. Hal ini bisa dipicu oleh bencana alam dan perubahan social. Menilik banyak kasus bunuh diri yang terjadi di Indonesia, dapat dilihat sebagai kasus bunuh diri anomic sebagai akibat dari perubahan situasi social yang begitu menghimpit.

\section{Teori Model Bunuh Diri}

Terdapat beberapa model yang dapat digunakan untuk menjelaskan munculnya perilaku bunuh diri ${ }^{5}$ : (a) Overlap model. Dikembangkan oleh Blumenthal \& Kupfer (1986) dengan gambaran lima buah diagram venn yang saling berhubungan. Lima area tersebu adalah: (1) kelompok psikososial (biasanya dilihat sebagai dukungan social), (2) kerentanan biologis (perkembangan biologis dan usia senja), (3) gangguan psikiatris (gangguan perasaan, skizopren dan gangguan mental organis), (4) faktor kepribadian seperti merasa sedih, depresi dan impulsif, (5) sejarah keluarga dan genetik. Secara teoritis persinggungan dari setiap faktor ini memunculkan resiko perilaku bunuh diri. (b) Three element model. Model tiga elemen diperkenalkan oleh Jacobs et al., 1999 yang mencakup faktor bawaan, faktor potensial dan faktor ambang batas bunuh diri. Berbagai variasi elemen dapat sebagai penyebab yang mendorong seseorang melakukan bunuh diri. (c) Suicide trajectory model. Model trajektori bunuh diri ini merupakan salah satu model interaktif multi dimensi yang dikembangkan oleh Stillion et al pada Tahun 1989 untuk menjelaskan munculnya pemikiran untuk bunuh diri. Resiko biologis, psikologis, kognitif dan faktor lingkungan saling berinteraksi membawa seseorang pada keputusan mengakhiri hidupnya. Faktor biologis mengacu 
pada predisposisi depresi secara genetik dan juga peran menjadi laki-laki. Faktor psikologis termasuk depresi, keputusasaan, ketidakberdayaan, rendahnya harga diri, dan kurangnya kemampuan melakukan koping. Faktor kognitif memperlihatkan adanya kekakuan dan gangguan kognitif. Faktor lingkungan termasuk didalamnya pengalaman keluarga yang negatif dan berbagai peristiwa hidup yang inilah menghubungan pikiran mengenai bunuh diri sebagai suatu pilihan tindakan yang dapat diambil. Dan munculnya peristiwa pencetus akan dengan mudah memicu bunuh diri. (d) Cubic Model. Model ini dikembangkan oleh Shneidman pada tahun 1987 dengan mengambarkan proses psikologis seseorang untuk sampai pada keputusan bunuh diri melalui sebuah kotak yang terdiri dari tiga taraf yaitu : tekanan, rasa sakit dan kegelisahan atau kekacauan. Tekanan merujuk pada suatu peristiwa yang mendorong seseorang melakukan reaksi. Tekanan ini dapat bersifat positif dan dapat pula bersifat negatif. Tekanan yang bersifat negatif misalnya, penghinaan, penolakan dan kegagalan tetapi ini diinterpretasikan sebagai suatu bencana besar.

Rasa sakit, rasa sakit secara psikologis adalah hasil dari dihalanginya kebutuhan psikologis ${ }^{6}$, bisa dari yang ringan tanpa tidak ada rasa sakit sampai ke rasa sakit psikologis yang tidak tertoleransi. Beberapa hal yang juga menjadi pencetus perilaku bunuh diri adalah kebutuhan psikologis untuk mandiri, berprestasi, mendapatkan pengakuan, pertolongan, dan dijauhkan dari rasa malu, penghinaan, dan rasa sakit. Kegelisahan atau kekacauan, kondisi sedih yang dapat bersumber dari faktor yang berkaitan berkaitan dengan kekakuan kognitif dan persepsi yang berkontribusi banyak terhadap bunuh diri.

\section{Faktor Resiko}

Shneidman at al (dalam Duran dan Barlow, 2006) ${ }^{7}$ menguraikan beberapa faktor resiko yang dapat menggambarkan kerentanan seseorang terhadap bunuh diri yaitu : (1)Riwayat keluarga. Resiko bunuh diri dapat terjadi jika ada salah satu anggota keluarga yang melakukan bunuh diri atau pernah mencoba melakukan bunuh diri. Faktanya Brent dan kawan-kawan mencatat bahwa resiko percobaan bunuh diri meningkat enam kali lipat pada anak dari anggota keluarga yang pernah berusaha bunuh diri dibandingkan dengan anak yang belum pernah mencoba.(2) Neurobiologi. Level serotonin yang rendah menunjukkan keterkaitan yang tinggi (Asberg, Nordstrom, \& Traskman-Bendz, 1986; Cremniter et al, 1999; Winchel, Stanley \& Stanley, 1990) level serotonin yang rendah memepengaruhi impulsivitas, instabilitas dan kecenderungan untuk memberikan reaksi yang berlebihan terhadap berbagai situasi (Spoon, 1992). (3) Gangguan psikologis yang sudah ada. Lebih dari 90 \% orang yang melakukan bunuh diri menderita ganguan psikologis tertentu (Black \& Winokur, 1990;Brent \& Kolko, 1990; Conwell et al, 1996; Garlan \& Zigler, 1993;Orbach, 1997). Bunuh diri sering kali berhubungan dengan 
gangguan suasana perasaan dan ada alasan yang kuat untuk itu. Sebanyak 60 $\%$ dari seluruh bunuh diri (75\% di antara bunuh diri dilakukan oleh remaja) berhubungan dengan gangguan suasana perasaan yang sudah ada (Brent dan Kolko, 1990; Frances dkk., 1986) Lewihnson, Rohde \& Seeley (1993) menyimpulkan bahwa di kalangan remaja perilaku bunuh diri kebanyakan merupakan pengekspresian depresi berat. (4) Kejadian hidup yang hidup penuh tekanan. Faktor resiko yang paling penting pencetus bunuh diri adalah kejadian yang penuh tekanan berat yang memalukan atau membuat orang merasa terhina, misalnya kegagalan (nyata ataupun tidak) di sekolah atau di tempat kerja, penahanan yang terjadi di luar dugaan dan cinta yang bertepuk sebelah tangan (Blumenthal, 1990;Brent dkk, 1988;Conwell dkk, 2002;Schaffer, Garland, Gould, Fisher \& Trautmen, 1988; Joiner \& Rudd, 2000)

Penelitian yang dilakukan Westefeld, Range, Rogers, Maples, Bromley Dan Alcorn ${ }^{8}$ menguraikan beberapa faktor resiko bunuh diri antara lain: (1) Kepribadian : depresif, pencemas, memiliki temperamen yang tidak menyenangkan, mudah tersinggung, kurang memiliki kemampuan untuk mengatur emosinya. (2) Kognisi : tidak berdaya, lebih perfeksionis, memiliki pikiran yang irasional, memiliki alasan yang lemah untuk hidup, eksternal lokus, tidak punya harapan, lebih suka dan lebih mudah mengingat pengalaman yang menyedihkan dibandingkan dengan pengalaman yang positif. (4) Tekanan lingkungan : memiliki sejarah kekerasan fisik dan seksual, lingkungan keluarga yang tidak memberikan dukungan, sulit menjalin hubungan yang langgeng dengan orang lain. (5) Alkohol dan penggunaan zat terlarang : berdasarkan penelitian dilaporkan bahwa orang yang selalu mencoba untuk bunuh diri mengkonsumsi alkohol dan obat-obatan terlarang lebih bayak dari teman sebayanya yang tidak menggunakan. (6) Perilaku : perilaku spesifik yang selalu diperlihatkan orang yang memiliki kecenderungan bunuh diri adalah : emosi yang negatif, gangguan berfikir, penggunaan alkohol dan zat terlarang. Memiliki sejarah tentang bunuh diri, sering membicarakan tentang bunuh diri, usaha yang selalu gagal semakin membuat seseorang memiliki kecenderingan tinggi untuk mengulangi usaha bunuh diri. Sering mengatakan ingin bunuh diri. (7) Penyakit fisik.

Faktor lingkungan yang beresiko terhadap bunuh diri menurut Perkins dan Hartless 9 :(1) Faktor individu : konsumsi alkohol menempati urutan terbesar dari pencetus seseorang bunuh diri (Apter et al., 1993;Brent et al., 1988; Dukes \& Lorch, 1989;Felts et al., 1992;Garrison, McKeown, Valois, \& Vincent, 1993; Kandel \& Raveis, Davies,1991; Shaffi, Carrigan, Whittinghill \& Derrick, 1985; Windle, Miller-Tutzauer, Barnes, \& Welte, 1991; dalam Perkins \& Hartless, 2002). Putus asa (Dukes, Lorch, 1989;Rubenstein et al, 1989;Rudd, Rajab \& Dahm, 1993, 1994; Shotte \& Chum, 1982, 1987), rendahnya tingkat religiusitas (Kandel et al, 1991), kekerasan seksual dan fisik (Brent et al, 1994). Rudd menemukan terdapat pengaruh yang kuat antara keputusasaan terhadap 
ide dan perilaku bunuh diri. (2) Faktor keluarga : rendahnya dukungan keluarga (Garrison, Jackson, Addy, Mc Keown \& walter, 1991; Garrison et al., 1993;Kandel et al., 1991;Lewinshon, Rohde \& Seeley, 1993;Rudd, 1994 dalam Perkins \& Hartless, 2002) orangtua yang menggunakan obatan terlarang (Brent et al, 1994) dalam hal ini kurang nya monitoring kepada anak sebagai salah satu bentuk tidak tersedianya dukungan social. (3) Faktor di luar keluarga : terasing secara sosial, kurang memiliki teman (lewinshon et al., 1993, 1994;Rubenstein et al., 1989;Rudd et al., 1993; dalam Perkins \& Hartless, 2002), kurang memiliki pengalaman yang positif di sekolah (Kandel et al., 1991) kurang terlibat dalam kegiatan ekstrakurikuler sekolah. Alasan lain yang juga mendorong anak memiliki ide bunuh diri adalah tidak menyatu dengan dengan baik di sekolah (Rubeinstein dalam Perkins \& Hartless 2002)

Berdasarkan tiga penelitian diatas dapat disimpulkan faktor resiko terhadap perilaku bunuh diri dapat bersumber dari kondisi internal pribadi dengan kondisi psikologis yang terganggu terutama dalam keadaan depresi dan frustasi, kemudian faktor biologis, berupa penyakit fisik ataupun juga mengalami gangguan sistem syaraf yang berimplikasi langsung pada keberlangsungan hormon. Kemudian faktor lingkungan baik keluarga maupun yang bersumber dari luar keluarga.

Membahas mengenai faktor resiko akan memudahkan kita untuk melihat kasus bunuh diri ini secara rinci untuk dapat menentukan langkah dan tahapan apa yang kita rancang untuk membuat program identifikasi dan prevensi.

\section{Bunuh Diri Sebagai Bentuk Kekerasan pada Anak}

Selama bunuh diri hanya dianggap sebagai suatu peristiwa yang sering dilakukan oleh seseorang baik anak, remaja maupun dewasa untuk menyelesaikan masalah, maka selama itu pula kita tidak dapat mengatakan bahwa bunuh diri memberi pengaruh buruk kepada anak. Apakah itu bunuh diri yang dilakukan oleh orang tua, teman, atau individu yang bersangkutan atau anggota keluarga yang lain. Karena sebuah problem besar justru muncul ketika tindakan bunuh diri dilakukan oleh orang tua (yang menganggap tindakan itu sebagai solusi akhir) dan disaksikan oleh anak. Kematian yang tiba-tiba dan dengan cara yang dianggap masyarakat sebagai sesuatu yang tidak lazim menjadi problem sendiri bagi orang yang ditinggalkan.

Penelitian Wright dan Partridge menyebutkan bahwa tindakan bunuh diri yang dilakukan oleh orang tua dapat dikatakan sebagai salah satu bentuk kekerasan mengingat efek yang ditimbulkan setelah munculnya peristiwa itu $^{10}$. Anak -anak yang kehilangan ayah karena bunuh diri dilaporkan merasa sedih yang berkepanjangan jika mengingat peristiwa tersebut, mencoba untuk mengindari ingatan tersebut, menderita beberapa keluhan somatis, dan menjadi ketakutan jika suatu hari hal yang sama terjadi pada anggota keluarga. 
Pengaruh lain yang timbul pada anak yang menyaksikan langsung peristiwa bunuh diri adalah PTSD dan beberapa anak yang menyaksikan merasa bertanggung jawab terhadap kematian tersebut. Tanggung jawab tersebut juga dialihkan pada sikap menyalahkan diri sendiri dan anggota keluarga yang lain. Dan pengalaman melihat kematian dengan cara seperti itu merupakan pengalaman yang merusak (abusive experience).

Tindakan bunuh diri yang disaksikan anak dapat dikatakan sebagai bencana bagi anak, tidak hanya karena menyaksikan sesuatu yang tidak menyenangkan berkenaan dengan kematian, hal ini juga merupakan sesuatu yang traumatis, dan juga kehilangan orang yang berarti dalam kehidupannya. Beberapa penelitian juga menemukan hal yang sama bahwa tidak berapa lama setelah menyaksikan peristiwa bunuh diri, individu mengalami gangguan emosional seperti depresi, kecemasan, menarik diri, merasakan kemarahan, dan agresi

Ibu atau ayah sebagai pasangan yang ditinggalkan juga merasakan kemarahan terhadap keputusan pasangan mengakhiri hidupnya, ia juga didera perasaan bersalah dan berharap dapat melakukan sesuatu untuk mencegah hal itu terjadi. Tantangan besar bagi pasangan yang ditinggalkan adalah menghadapi lingkungan social atas apa yang menimpa keluarga mereka dalam rangka melindungi anak dari situasi yang lebih menekan

Penelitian Saarinen et $\mathrm{al}^{11}$ menunjukkan bahwa kematian pasangan akibat bunuh diri memicu pasangan yang masih hidup untuk menempuh cara yang sama. Ia juga menyebutkan bahwa seorang ibu yang bertahan dari kematian anaknya akibat bunuh diri mengalami gangguan psikologis berupa depresi dan reaksi yang abnormal terhadap kematian. Sedangkan untuk menghindari resiko perkembangan pada anak dibutuhkan ibu dengan kesehatan mental yang baik. Hal yang tidak kalah penting adalah bagaimana mendampingi anak dan memberi pamahaman baru kepada anak tentang peristiwa yang mereka alami. Bagaimana cara merekonstruksi pengalaman yang menyakitkan tersebut menjadi sesuatu yang positif.

Sebagaimana yang telah dijelaskan oleh Shneidman (dalam Davison, Neale \& Kring, 200 bahwa salah satu kondisi umum yang terjadi pada peritiwa bunuh diri adalah bunuh diri sebagai suatu konsistensi pola coping sepanjang hidup ${ }^{12}$. Dengan penilaian ini maka dapat kita katakan bahwa tindakan bunuh diri merupakan bentuk kekerasan yang memiliki efek jangka panjang pada pola pikir, perilaku dan kondisi psikologis orang yang ditinggalkan. Bagaimana peristiwa yang terekam dalam benak anak ketika menyaksikan orangtua bunuh diri atau mati karena bunuh diri. Contoh terdekat adalah bagaimana salah seorang Bapak di Sumatra Utara yang membunuh anaknya dengan meminumkan kopi yang dibubuhi racun, usahanya untuk membawa serta semua anaknya gagal, karena anak perempuan menolak meminum dan dengan mata kepala sendiri ia menyaksikan Bapak dan Kakaknya meregang nyawa ${ }^{13}$. 
Jagues $^{14}$ (2000) menyebutkan bagaimana anak-anak yang bertahan dari kematian saudaranya akibat bunuh diri menjadi merasa tidak aman dan ketakutan karena melihat perubahan keluarga yang begitu tiba-tiba, merasa bahwa orang tua yang larut dalam kesedihan tidak lagi dapat diraih dan yang muncul adalah perasaan terabaikan. Kondisi memaksa mereka bertindak menjadi orangtua bagi orang tua mereka sendiri. Sedangkan di saat bersamaan sebagai anak ia juga ingin haknya dipenuhi.

Demikianlah beberapa efek jangka panjang dari tindakan bunuh diri, tidak hanya beresiko memunculkan gangguan psikologis secara perorangan anak, orangtua, saudara kandung di dalam keluarga tetapi juga dapat masyarakat secara luas. Terlebih lagi dengan adanya media yang memberitakan peristiwa bunuh diri.

\section{Pengaruh Media Masa terhadap Perilaku Bunuh Diri}

Gould ( dalam Durand dan Barlow, 2006) menjelaskan bahwa terjadi peningkatan perilaku bunuh diri setelah sembilan hari adanya publisitas tentang bunuh diri ${ }^{15}$. Dan fenomena ini pula yang kita dapati pada. kasus di indonesia. Hanya dalam rentang waktu yang singkat telah terjadi beberapa peristiwa bunuh diri.

Pengaruh media terhadap peningkatan bunuh diri dapat ditilik dari beberapa hal : (1)peristiwa bunuh diri seringkali didramatisasi oleh media, (2) pemberitaan media seringkali menggambarkan secara rinci metode-metode yang digunakan untuk bunuh diri secara rinci sehingga dapat dijadikan pedoman bagi calon korban, (3) Media jarang memberitakan konsekuensi bunuh diri dan ketidak efektifan bunuh diri dalam mengatasi masalah.

Pengaruh media terhadap meningkatnya perilaku bunuh diri juga dibahas oleh Bandura berdasarkan penelitian Philips tahun 1974, 1977, 1985 yang menunjukkan hubungan sebagi berikut : (1) bunuh diri meningkat hingga 12 persen pada bulan berikutnya menyusul kematian Marylin Monroe, (2) publikasi berbagai kematian karen tindakan bunuh diri yang dilakukan oleh orang-orang yang tidak terkenal juga diikuti peningkatan angka bunuh diri secara signifikan, menunjukkan bahwa hal yang menjadi penting adalah publisitas itu sendiri bukan kepopuleran orang tersebut, (3)Publikasi peritiwa pembunuhan-bunuh diri diikuti oleh meningkatnya kecelakaan mobil dan pesawat di mana pengemudi dan penumpang tewas (4) Berbagai laporan media tentang kematian wajar orang-orang yang terkenal tidak diikuti oleh peningkatan angka bunuh diri, menunjukkan bahwa bukan rasa duka cinta semata yang merupakan faktor yang berpengaruh ${ }^{16}$.

Berdasarkan fakta diatas dapat disimpulkan bahwa dari pemberitaan media terjadi proses pembelajaran secara sosial dimana seseorang belajar melalui pengamatan terhadap perilaku orang lain. 


\section{Prevensi dan Proteksi Berbasis Sekolah}

Berdasarkan dari uraian faktor resiko pencetus tindakan bunuh diri diatas, dapat kita lihat bahwa gangguan psikologis seperti depresi dan penggunaan alkohol menempati persentasi terbesar. Selain kondisi lingkungan keluarga dengan dukungan sosial yang mimin. Untuk itu dalam rangka melakukan tindakan prevensi sebagai proteksi ada beberapa hal yang dapat dilakukan yaitu : (1) menangani gangguan mental yang mendasari : sebagian besar orang yang melakukan bunuh diri mengalami gangguan mental yang dapat ditangani. Dengan demikian menggunakan pendekatan kognitif sebagaimana yang telah dikembangkan oleh Beck terbukti dapat menurunkan resiko bunuh diri pada pasien.Pendekatan lain yang dapat digunakan adalah pendekatan DBT (Dialectic Behavior Therapy) ${ }^{17}$. DBT terbukti dapat menurunkan ide dan pikiran untuk bunuh diri dengan cara menekankan pada diri klien akan pentingnya hubungan interpersonal dan penerimaan sosial. Hal ini secara spesifik ditujukan untuk meningkatkan karakteristik pribadi untuk meningkatkan predisposisi yang positif dan mengembangkan kemampuan melakukan pemecahan masalah sebagai faktor protektif. (2) menangani kemungkinan bunuh diri secara langsung18 (Shneidman, 1987 dalam Davison, Neale \& Kring, 2006) dengan mengembangkan strategi umum yang mencakup tiga hal : (a) peneritaan dan rasa sakit psikologis yang mendalam, (b) membuka pandangan yaitu memperluas pandangan yang terbats dengan membantu individu melihat berbagai pilihan selain pilihan yang ektrem dengan membiarkan penderitaan dan ketiadaan terus berlangsung, (c) mendorong orang yang bersangkutan untuk mundur meskipun hanya selangkah dari tindakan yang menghancurkan diri sendiri.(3) melakukan terapi keluarga : faktor keluarga sebagai salah satu penyumbang besar dorongan tindakan bunuh diri merupakan apek penting untuk dijadikan faktor proteksi, ketersediaan dukungan keluarga, keterbukaan dan harmonisnya keluarga dapat menurunkan tingkat bunuh diri pada diri klien ${ }^{19}$ (Sprague, 1997). Keterbukaan komunikasi antar anggota keluarga dan sikap orang tua yang tidak terlalu menaruh harapan yang tinggi terhadap anak juga dapat digunakan sebagai faktor proteksi.

Selain itu intensitas komunikasi yang positif dengan orang dewasa yang berkompeten juga merupakan salah satu faktor protektif yang penting. (1) kebanyakan orang tua sulit sekali membicarakan kematian dengan anak terlebih lagi kematian dengan melukai diri sendiri hingga tewas. Dalam hal ini merupakan sesuatu yang penting untuk didiskusikan dalam rangka memahamkan kepada anak tentang apa yang mereka hadapi baik secara langsung maupun dari media. Sehingga supervisi terhadap orang tua menjadi agenda penting dalam upaya melakukan proteksi. Tujuan akhir dari kegiatan ini adalah : (1) Menjelaskan pengalaman merusak tentang bunuh diri, (2) Mengurangi perasaan bersalah, rasa marah, putus asa dan sedih, (3) Menjadi 
resiko tersendiri jika anak mengetahui alasan kematian orangtuanya karena bunuh diri dari orang lain.

Program prevensi merupakan komponen penting dalam proses konseling. bentuk prevensi bagi tindakan bunuh diri dapat beragam yaitu membuat pusat pencegahan bunuh diri. Pusat ini menyediakan layanan bagi penanganan ide ataupun tinadakan yang sudah mengarah pada usaha membunuh diri. Salah satu contoh pusat pencegahan tindakan bunuh diri adalah Los Angeles Suicide Prevention Center yang didirikan pada tahun 1958 oleh Farberow dan Shneidman. Selain dapat digunakan sebagai wadah untuk melakukan pencegahan tindakan bunuh diri, organisasi ini juga berguna bagi pencatatan kasus -kasus bunuh diri untuk dapat menentukan program penanganan yang tepat.

Kalafat (2003) Membuat program edukasi untuk mencegah bunuh diri yang dapat dikembangkan berbasis sekolah ${ }^{20}$. Sebagaimana yang dilaporkan pada penelitiannya tentang prevensi tindakan bunuh diri pada remaja berbasis sekolah dengan menggunakan pendekatan yang dikembangkan oleh Institute of medicine terdiri dari tiga kategori program prevensi yaitu (1) Intervensi secara universal. Intervensi ini diberlakukan secara global dengan melibatkan berbagai pihak yang ada di sekolah seperti teman, orang tua, guru, petugas administrasi hingga penjaga gerbang sekolah. Pendekatan ini dianggap cukup efektif karena berbagai interaksi banyak terjadi di dalam lingkungan sekolah sehingga dalam setiap kesempatan baik guru, maupun teman yang berkompeten dapat dijadikan suatu sitem dukungan sosia ${ }^{21}$. Fokus utama prevensi diarahkan pada menyediakan pelatihan untuk guru, remaja bagaimana cara mengidentifikasi siswa yang beresiko akan melakukan bunuh diri, dengan harapan kerentanan seseorang dapat dibantu sebelum perilaku itu muncul. Misalnya perilaku suka melukai diri sendiri maka pihak sekolah harus merujuk anak tersebut ke ahli yang berkompeten. Juga mengajarkan anak tentang coping yang baik. (2) Intervensi selektif. Program ini dikenal dengan istilah Reconnecting Youth untuk kembali melibatkan anak-anak yang bermasalah sehingga tersisih secara sosial ke dalam lingkungan sekolah kembali. Program ini terdiri dari empat komponen program yaitu : aktivitas sekolah, keterlibatan orang tua, perencanaan respon sekolah terhadap krisis yang dialami oleh remaja di sekolah, dan kelas reconnecting yang ditawarkan untuk diikuti oleh remaja yang bermasalah.(3) Intervensi yang secara spesifik ditujukan untuk anak-anak yang memang telah memiliki gangguan klinis. Intervensi ini tentusaja melibatkan pihak-pihak yang berkompeten di bidangnya sehingga sekolah menjalin jejaring untuk dapat merujuk siswa yang mengalami permasalahan tertentu agar tidak sampai pada melakukan tindakan bunuh diri.

\section{SIMPULAN}


Pada umumnya peristiwa bunuh diri biasanya didahului oleh depresi yang melanda pelakunya. Depresi yang didahului oleh frustasi, yakni situasi di mana seseorang tidak mampu mencapai tujuan yang diinginkannya. Sedangkan frustasi didahului oleh stress, yakni respon individu terhadap keadaan yang mengancam dan mengganggu kemampuan seseorang untuk menghadapinya.. Anak memiliki resiko tersendiri dalam peristiwa bunuh diri yang dilakukan oleh orang tua. Bisa saja anak yang tidak berdosa dibawa bersama oleh orang tua untuk bunuh diri atau anak menerima dampak psikologis baik lansung atau tidak lansung dari peristiwa tersebut.Dengan demikian, peristiwa bunuh diri dapat dikatakan sebagai salah satu bentuk kekerasan kepada anak, apakah anak terlibat langsung sebagai korban, sebagai yang menyaksikan ataupun sebagai yang ditinggalkan dengan sejuta pertanyaan di kepalanya. Banyak fakor penyebab orang melakukan bunuh diantaranya kondisi psikologis, biologis, dan lingkungan baik keluarga maupun yang bersumber dari luar keluarga. Pencegahan bunuh diri dapat dilakukan dengan melakukan prevensi dan proteksi berbasis sekolah . Kegiatan ini tentu saja melibatkan pihak-pihak yang berkompeten di bidangnya sehingga sekolah menjalin jejaring untuk dapat merujuk siswa yang mengalami permasalahan tertentu agar tidak sampai pada melakukan tindakan bunuh diri.

\section{Endnotes:}

www. Kompas.co.id/Tekanan Ekonomi Memicu Kekerasan. Tanggal 10 Juni 2008

2 Davison, G.C., Neale, J.M., \& Kring, A.M. 2006. Psikologi Abnormal. Jakarta: RajaGrafindo Persada

3 Ibid

$4 \quad$ Ibid

5 Westefed, J.S et al. 2000. Suicide : An Overview. The counseling psychologist. 28, 445

6 Op.Cit

7 Duran, V.M \& Barlow, D.H. 2006. Psikologi Abnormal.Jogjakarta: Pustaka Pelajar

8 Westefed, J.S et al. 2000. Suicide : An Overview. The counseling psychologist. 28, 445

9 Perkins, D.F \& Hartless, G. 2002. An Ecological Risk Factor Examination Of Suicide Ideation And Behavior Of Adolescents. Journal Of Adolescent Research. 17, 3

10 Wright, B \& Partridge, I. 1999. Speaking Ill Of The Dead: Parentan Suicide As child Abuse. Clinical child psychology and psychiatry. 4, 225

11 Saarinen, P.I et al. 2000. Is It Impossible To Adapt Suicide Of A Close Individual? Result Of A 10Years Prospective Follow Up Study. International Journal Of Social Psychiatry. 46, 182

12 Davison, G.C., Neale, J.M., \& Kring, A.M. 2006. Psikologi Abnormal. Jakarta: RajaGrafindo Persada

13 (Kompas.com, 2007)

14 Jacques, J.D. 2000. Surviving Suicide: The Impact On The Family. The Family Journal. 8, 376

15 Duran, V.M \& Barlow, D.H. 2006. Psikologi Abnormal.Jogjakarta: Pustaka Pelajar

16 Davison, G.C., Neale, J.M., \& Kring, A.M. 2006. Psikologi Abnormal. Jakarta: RajaGrafindo Persada 
17 Davison, G.C., Neale, J.M., \& Kring, A.M. 2006. Psikologi Abnormal. Jakarta: RajaGrafindo Persada

Sprague, T. 1997. Clinical Management Of Suicidal Behavior In Children And Adolescent. Clinical Child Psychology And Psychiatry. 2, 113

20 Kalafat, J. 2003. School Approaches To Youth Suicide Prevention. American Behavioral Scientist. 46,1211

Bee, H \& Boyd. D. 2007. The Developing Child.Boston : Pearson Education.inc

\section{DAFTAR PUSTAKA}

Bee, H \& Boyd. D. 2007. The Developing Child.Boston : Pearson Education.inc

Brown, C.H et al. 2006. Dynamic Wait-Listed Design For Randomized Trials: New Design For Prevention Of Youth Suicide. Clin Trial. 3, 259

Davison, G.C., Neale, J.M., \& Kring, A.M. 2006. Psikologi Abnormal. Jakarta: RajaGrafindo Persada

Duran, V.M \& Barlow, D.H. 2006. Psikologi Abnormal.Jogjakarta: Pustaka Pelajar

Gould, M., Jamieson, P \& Romer, D. 2003. Media Contagion And Suicide Among The Young. American Behavioral Scientitist. 42, 1269

Jacques, J.D. 2000. Surviving Suicide: The Impact On The Family. The Family Journal. 8, 376

Kalafat, J. 2003. School Approaches To Youth Suicide Prevention. American Behavioral Scientist. 46, 1211

Lehnert, K.L \& Overholser, J.C. 1994. Internalized And Externalized Anger In Adolescent Suicide Attempters. Journal Of Adolescent Research. 9, 105

Perkins, D.F \& Hartless, G. 2002. An Ecological Risk Factor Examination Of Suicide Ideation And Behavior Of Adolescents. Journal Of Adolescent Research. 17, 3

Saarinen, P.I et al. 2000. Is It Impossible To Adapt Suicide Of A Close Individual? Result Of A 10-Years Prospective Follow Up Study. International Journal Of Social Psychiatry. 46, 182

Sprague, T. 1997. Clinical Management Of Suicidal Behavior In Children And Adolescent. Clinical Child Psychology And Psychiatry. 2, 113

Westefed, J.S et al. 2000. Suicide : An Overview. The counseling psychologist. 28, 445

Wright, B \& Partridge, I. 1999. Speaking Ill Of The Dead: Parentan Suicide As child Abuse. Clinical child psychology and psychiatry. 4, 225 
www. Kompas.co.id/Tekanan Ekonomi Memicu Kekerasan. Tanggal 10 Juni 2008 